\title{
Effect of soybean roots and a plough pan on the movement of soil water along a profile during rain
}

\author{
Dong Wencai $^{1} \mathbb{D} \cdot$ Cai Fangfei $^{1} \cdot$ Fu Qiang $^{1} \cdot$ Cao Chengpeng $^{2} \cdot$ Meng Xue $^{1} \cdot$ Yang Xianye $^{3}$
}

Received: 1 April 2019 / Accepted: 2 July 2019 / Published online: 8 July 2019

(c) The Author(s) 2019

\begin{abstract}
The movement of water into soil is the primary driving force in nutrient transport for crops, and the laws governing this movement can be affected by crop roots and plough pans. The main objectives of this study were to monitor the movement of water during rain along a soil profile influenced by soybean roots and a plough pan and to assess whether these factors influenced the efficacy of using the Richards equation to simulate the transport of soil water along a profile associated with a single rain. Experiments and model simulations were carried out. Our results suggested that the soybean field soil may have had preferential flow paths. Soybean stems and leaves transferred rainwater that otherwise would have fallen farther from the central stalk. The transmission of rainwater by the branches and leaves had a larger effect than the interception of rainwater by the branches and leaves. The effect of the root system on the soil particles may increase soil capillary action and ultimately increase saturated hydraulic conductivity. Saturated hydraulic conductivity was higher near the surface than at depth, because the transmission of water by the root system and the effect of large gaps were greater in the soil near the surface. Saturated hydraulic conductivity for both bare land and land covered with soybean plants decreased linearly from depths of 0-15 cm along the soil profile, particularly in the presence of a plough pan. We developed a linear equation to represent the variation in saturated hydraulic conductivity in the $0-15-\mathrm{cm}$ layer in the black soil area of northeastern China. Using our linear model for saturated hydraulic conductivity as a parameter, the Richards equation more accurately simulated soil water transport along a profile influenced by soybean roots and a plough pan in rainy conditions.
\end{abstract}

Keywords Soybean root $\cdot$ Plough pan $\cdot$ Rainfall $\cdot$ Infiltration model $\cdot$ Saturated hydraulic conductivity

\section{Introduction}

Rainfall infiltration is an important process that results in the formation of soil water. Infiltration is affected by various rainfall characteristics as well as by the physical and chemical characteristics of soil. The biological environment of the soil can also be an important factor (Huang et al. 2010). Because of the number of factors that influence cultivated land, soil moisture transfer is an important area for agricultural scientific research and of great significance to

Dong Wencai

wencai80923@163.com

1 College of Water Conservancy and Architecture, Northeast Agricultural University, Harbin 150030, Heilongjiang, China

2 College of Agriculture and Hydraulic Engineering, Sui Hua University, Suihua 152061, Heilongjiang, China

3 Guangdong Polytechnic of Water Resources and Electric Engineering, Guangzhou 510635, Guangdong, China agricultural production. The movement of nutrients is also important for research into soil water movement, which could help scientists and farmers to develop site-specific agricultural practices.

Plant roots and plough pans are particularly important factors affecting the vertical movement of soil water. Plant roots have clear positive effects on the vertical movement of soil water. The root network and the consolidation of soil with single-particle bonding improve the granular structure and porosity of soil near the roots, directly influencing soil permeability (Czarnes et al. 2000; Hagedorn and Bundt 2002). However, microgrids are formed at connection points to prevent the movement of soil particles. The particles deposited in these connections enable the direct in situ infiltration of runoff (Wang et al. 1996). The presence of plant roots increases the number of large gaps in the soil layer where roots are distributed. The distribution characteristics of large gaps vary greatly (Qu et al. 1999; Cullum 2009; Lamandé et al. 2011; Mooney 2002) and decrease 
with increasing depth (Noguchi et al. 1997; Pierret et al. 2002), further enhancing the differences in soil hydraulic conductivity along the soil profile (Pierret et al. 2002). A study by Roberto proposed a model for water infiltration in the presence of large gaps (Greco 2002). However, the model cannot be applied to scenarios that include plant roots and plough pans. The compacted soil of plough pans decreases vertical movement (Wilkinson and Aina 1976; Ankeny et al. 1990, 1995; Freese et al. 1993; Potter et al. 1995; Mohanty et al. 1996; Vervoort et al. 2001; Martínez et al. 2008; Bertolino et al. 2010), saturated hydraulic conductivity (Logsdon et al. 1992; Liebig et al. 1993; Arvidsson 2001), and porosity (Alakukku 1996a, b; Richard et al. 1999; Radford et al. 2000) and increases bulk density (Horn et al. 1995; Xu and Mermoud 2001). There is extensive literature addressing the morphological evidence for soil compaction (Horn et al. 1995; Gantzer and Anderson 2002), but few studies address this evidence as it relates to plough pans (Boizard et al. 2002) and their hydrological effects (Bertolino et al. 2010). The emergence of a plough pan adds complexity to the internal soil structure, and with the additional effects of crop roots, significant differences in soil water migration were observed for homogeneous soil.

The objectives of this study were to determine the effects of soybean roots and plough pans on soil water movement along a profile during rain by a field experiment and model simulation and to test the applicability of the Richards infiltration model under the influence of soybean roots and a plough pan.

\section{Materials and methods}

We focused on water transport during rainfall in soil characterized by a soybean root system and a plough pan. In the conceptual model, the soil in the study field was divided into two vertically distributed horizontal layers: the soybean root system layer and the underlying soil (bulk density of the plough pan was $1.38 \mathrm{~g} / \mathrm{cm}^{3}$, much higher than the soil above the plough pan). Under the influence of large gaps and a soybean root system, the saturated hydraulic conductivity decreases gradually from the surface in the soybean root system layer. Saturated hydraulic conductivity changes very little in the plough pan and is much lower than in the plough layer above it. By disregarding increases in water supply around the root zone due to the interception and conduction of the stem and leaf, we assumed that saturated hydraulic conductivity decreases linearly in the soybean root system layer when large gaps and soybean root systems are present and is constant in the plough pan.

\section{Experimental methods}

Due to many years of cultivation, a plough pan has been formed in the black soil region of Northeast China, one of the world's three largest black soil areas. Experiments were carried out in Anda City, in the black soil region of Northeast China, located in Heilongjiang Province $\left(46.12^{\circ} \mathrm{N}\right.$, $\left.124.99^{\circ} \mathrm{E}\right)$. The experimental soil is classified as a loam in the USDA Soil Taxonomy System. The growing season lasts for approximately $120-130$ days. The effective accumulated temperature, defined as days with temperatures $\geq 10^{\circ} \mathrm{C}$, was $2700{ }^{\circ} \mathrm{C}$ for the growing season, and annual rainfall was approximately $400 \mathrm{~mm}$. The ground slope is $1 / 600$. The basic agricultural soil conditions are shown in Table 1. To determine the effects of the plough pan, soybean roots (with stem leaf and without stem leaf), and soybean leaves and stems on soil water movement, we designed 8 experimental treatments and completed 3 replicates of each for a total of 24 test plots; the area of each trial plot was $40 \mathrm{~m}^{2}$. Treatment 1 was characterized by bare land, not affected by sowing, or soybean coverage; the land remained under natural conditions. Plough pan depth was approximately $13 \mathrm{~cm} \pm 2 \mathrm{~cm}$ (ridge), plough pan bulk density was $1.38 \mathrm{~g} / \mathrm{cm}^{3}$, and soil bulk density was greater than $1.23 \mathrm{~g} / \mathrm{cm}^{3}$. Treatment 2 areas were ploughed deeply enough to break the plough pan, with a tillage depth $28 \mathrm{~cm} \pm 4 \mathrm{~cm}$. This treatment had a soil bulk density of $1.23 \mathrm{~g} / \mathrm{cm}^{3}$ and was characterized by bare land with no sowing. Treatment 3 was under natural conditions but with soybean coverage. Plough pan depth was approximately $13 \mathrm{~cm} \pm 2 \mathrm{~cm}$ (ridge), and plough pan bulk density was $1.38 \mathrm{~g} / \mathrm{cm}^{3}$. Soil bulk density was greater than $1.23 \mathrm{~g} / \mathrm{cm}^{3}$, and an artificial rainfall intensity of $0.121 \mathrm{~cm} /$ min was applied. Treatment 4 was pre-processed using the

Table 1 Chemical properties of the soil

\begin{tabular}{|c|c|c|c|c|c|c|c|c|c|c|}
\hline \multirow[t]{3}{*}{ Depth $(\mathrm{cm})$} & \multicolumn{3}{|c|}{ Particle size distribution (\%) } & \multirow{3}{*}{$\begin{array}{l}\text { Organic } \\
\text { matter \% }\end{array}$} & \multirow{3}{*}{$\begin{array}{l}\text { Total } \\
\text { nitrogen } \\
\mathrm{g} / \mathrm{kg}\end{array}$} & \multirow{3}{*}{$\begin{array}{l}\text { Total phos- } \\
\text { phorus g/kg }\end{array}$} & \multirow{3}{*}{$\begin{array}{l}\text { Alkaline } \\
\text { nitrogen mg/ } \\
\mathrm{kg}\end{array}$} & \multirow{3}{*}{$\begin{array}{l}\text { Available phos- } \\
\text { phorus mg/kg }\end{array}$} & \multirow{3}{*}{$\begin{array}{l}\text { Available } \\
\text { potassium mg/ } \\
\text { kg }\end{array}$} & \multirow[t]{3}{*}{$\mathrm{pH}$} \\
\hline & Clay & Silt & Sand & & & & & & & \\
\hline & $<0.002$ & $0.002-0.05$ & $>0.05$ & & & & & & & \\
\hline $0-20$ & 11.23 & 61.08 & 27.69 & 1.52 & 1.34 & 0.68 & 83 & 29.2 & 123 & 7.65 \\
\hline $20-40$ & 15.11 & 65.26 & 19.63 & 1.48 & 0.99 & 0.62 & 54 & 25.0 & 112 & 7.67 \\
\hline $40-60$ & 15.34 & 66.11 & 18.55 & 1.39 & 0.78 & 0.57 & 53 & 18.9 & 118 & 7.62 \\
\hline
\end{tabular}


same methods as treatment 3, but soybeans were cut along their cotyledon marks before rainfall. Treatment 5 also had the same conditions as treatment 3 but with an artificial rainfall intensity of $0.121 \mathrm{~cm} / \mathrm{min}$. Treatment 6 was the same as treatment 4 but with an artificial rainfall intensity of $0.148 \mathrm{~cm} / \mathrm{min}$. Treatments 7 and 8 used the same preprocessing methods as treatment 3 but with natural rainfall intensities of 0.073 and $0.113 \mathrm{~cm} / \mathrm{min}$, respectively. All treatments used a planting density of 26.8 million plants per hectare. Urea and diammonium phosphate were each applied at rates of $55 \mathrm{~kg} / \mathrm{hm}^{2}$ before sowing, and the high yielding Suinong 21 variety of soybean was used. Small farm tractors had continuously cultivated the field for 21 years before the land was tested, and the ploughing depth could be adjusted. Furrow ridges were formed after compaction to a height of $16 \mathrm{~cm} \pm$ about $2 \mathrm{~cm}$, and the ridge-till system had a ridge width of $0.67 \mathrm{~m}$. The same field management practices were used for all treatments. Artificial rainfall experiments and natural rainfall observations were completed during the grain filling stage of the soybeans.

To observe root characteristics during the grain filling stage, plants were cut at the first sign of a cotyledon, and a drilling method was used (Jin 2007; Dong et al. 2017). Each sample plot included 3 groups, and each group included random samples from 3 plots. Plots were located $5.0 \mathrm{~cm}$ from plants, and sampling depths were $0-15 \mathrm{~cm}, 15-30 \mathrm{~cm}$, $30-45 \mathrm{~cm}$, and 45-60 $\mathrm{cm}$ with a drill diameter of $15 \mathrm{~cm}$. Samples were soaked in water for $12 \mathrm{~h}$. Roots were slowly rinsed in a stream of water, and a 100-mesh sieve was placed underneath to prevent the loss of roots washed away by the water. The plant root analysis system LA-S (wseen) was used to determine the characteristics of the root system (Liu et al. 2015a, b). Washed root samples were placed in a $30 \mathrm{~cm} \times 40 \mathrm{~cm}$ Plexiglas tank and injected with water up to 3-4 $\mathrm{mm}$ deep, with roots fully spread. A double-sided light scan analysis was used to determine root length, surface area, volume, and diameter (Jin 2007). Root biomass was measured after drying roots in an oven set to $70{ }^{\circ} \mathrm{C}$. To sample the soil moisture profile, fields were covered with a canopy immediately after rainfall, and 1 soil sample was taken every centimetre along the vertical soil profile from depths of 1-20 cm. A soil drill (Xing Xing instrument equipment, Yangling, China) was used to collect samples for determining the initial soil water content before a rain (Table 2), with one sample collected every $3.0 \mathrm{~cm}$ from depths of 1-6 cm and one sample collected every $5.0 \mathrm{~cm}$ from 7 to $20 \mathrm{~cm}$. To measure the soil moisture content using the drying method (Dong et al. 2017), the oven temperature was set to $105{ }^{\circ} \mathrm{C}$ for more than $12 \mathrm{~h}$. One rainwater sample per minute was collected using a gauge $20 \mathrm{~cm}$ in diameter (TPJ-32). Soil samples were collected immediately after the rain stopped along a vertical section at $10-\mathrm{mm}$ intervals to analyse their water contents from 1 to $25 \mathrm{~cm}$ along the soil
Table 2 Initial soil moisture content for multiple rainfall treatments

\begin{tabular}{llll}
\hline Depth $(\mathrm{cm})$ & $\begin{array}{l}\text { Treatments 3, } \\
4,5,6(\%)\end{array}$ & Treatment 7 (\%) & Treatment 8 (\%) \\
\hline $1-3$ & 14.3 & 13.1 & 15.2 \\
$4-6$ & 19.4 & 18.2 & 17.4 \\
$7-9$ & 22.3 & 22.1 & 21.7 \\
$10-15$ & 22.4 & 22.3 & 21.8 \\
$16-20$ & 22.3 & 22.3 & 21.8 \\
\hline
\end{tabular}

profile. The main components of the rain simulator (artificial rain experiments) (NLJY-09-2, Nanlin Electronics Technology, Nanjing, China) were a set of nozzles $4.0 \mathrm{~m}$ above the soil surface. Rain intensity could be adjusted from 0 to $150 \mathrm{~mm} \mathrm{~h}^{-1}$. The length and width of the controlled area of the apparatus were 400 and $200 \mathrm{~cm}$, respectively. The target field was covered with a $600 \times 300 \mathrm{~cm}$ canopy before each rain to minimize the influence of natural rain intensity. The canopy was quickly removed when the intensity became uniform. Saturated water content, bulk density, and porosity (capillary:pores with obvious capillary action; large gap:pores without capillary action, and the water movement in the continuous large gap is dominated by the gravity potential) (Beven and Germann 1982) along the profile were determined as described by Liu and Li (1983). The position of the plough pan was determined by the bulk density. Water retention was determined as described by Fu et al. (2008). The other soil parameters were obtained for the vertical and horizontal (Wang et al. 2002) soil columns using infiltration experiments and the double-ring method (Yuan et al. 1999).

\section{Water movement equations}

The one-dimensional vertical movement of soil water is usually described by the Richards equation (Wallach et al. 1988; Gao et al. 2004, 2005; Dong and Wang 2013):

$\frac{\partial \theta(z, t)}{\partial t}=\frac{\partial}{\partial z}\left[D(\theta) \frac{\partial \theta(z, t)}{\partial z}-k(\theta)\right]$

where $t$ is time $(\min ), \theta$ is water content $(\%), D(\theta)$ is the soil-water diffusivity $\left(\mathrm{cm}^{2} / \mathrm{min}\right), K(\theta)$ is the unsaturated hydraulic conductivity $\left(\mathrm{cm} \mathrm{min}{ }^{-1}\right), \theta(z, t)$ is the water content at depth $z(\%)$, and $z$ is the vertical depth of the soil $(\mathrm{cm})$. The initial and boundary conditions imposed on Eq. (1) are

$$
\begin{array}{ll}
\theta=\theta_{i} & t=0 \quad z \geq 0 \\
D(\theta) \frac{\partial \theta(z, t)}{\partial z}-k(\theta)=-i & t>0 z=0 \\
\theta=\theta_{i} & t>0 z \rightarrow \infty
\end{array}
$$

where $\theta_{i}$ is the initial soil-water content (\%) and $i$ is the infiltration capacity of the soil $(\mathrm{cm} / \mathrm{min})$.

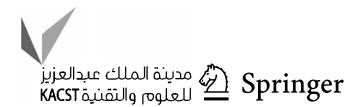


The soil-water diffusivity, $D(\theta)$, and the unsaturated hydraulic conductivity, $k(\theta)$, for the hydraulic properties of porous media were determined using the Brooks-Corey model (Brooks and Corey 1964):

$K(\Theta)=K_{\mathrm{s}} \Theta^{m}$

$D(\Theta)=\frac{K_{\mathrm{S}} h_{\mathrm{d}} \Theta^{l+1 / n}}{n\left(\theta_{\mathrm{S}}-\theta_{\mathrm{r}}\right)}$

$\Theta=\frac{\theta-\theta_{\mathrm{r}}}{\theta_{\mathrm{s}}-\theta_{\mathrm{r}}}$

where $n$ and $m$ represent shape parameters $(m=2+3 n), h_{\mathrm{d}}$ is the air entry suction, $l$ is the pore tortuosity ( 2 in the Brooks-Corey model), $\theta_{\mathrm{s}}$ is the saturated water content $(\%), \theta_{\mathrm{r}}$ is the retention water content $(\%)$ measured with the method used by Fu et al. 2008, and $\theta$ is the soil water content (\%). $\theta_{\mathrm{s}}$ and $\theta$ are measured directly. Vertical and horizontal infiltration was determined using soil column experiments following the method described by Wang et al. (2002) to determine the parameters $K s$ (saturated hydraulic conductivity), $n$, and $h_{\mathrm{d}}$ (Table 3 ).

According to Parlange $(1971,1972)$, the boundary conditions from the start of rainfall to soil saturation can be expressed as (Dong and Wang 2013):

$\theta_{0}^{\prime}(t)=-\frac{i}{\theta_{0}(t)-\theta_{i}} \frac{K\left[\theta_{0}(t)\right]-i}{D\left[\theta_{0}(t)\right]}$

where $\theta_{0}(t)$ is the water content of the soil surface (\%). Equation 6 is given by the Parlange transformation of Eq. 1. The boundary conditions of the surface soil water content were obtained by combining $D(\theta)$ and $K(\theta)$ with Eq. 6 . The water movement in the soil (Eq. 1) could then be determined using a number of different numerical methods.

Consistency between the model simulations and the measured soil water content data were quantified using root mean square errors (RMSEs) (Willmott 1982). The RMSE can be expressed as:

$\operatorname{RMSE}=\sqrt{\frac{\sum_{i=1}^{N}\left(p_{i}-o_{i}\right)^{2}}{N}}$

where $N$ is the total number of data points, $P_{i}$ is a simulated data point, and $O_{i}$ is a measured data point.

Table 3 Soil parameters for the model

\begin{tabular}{llllll}
\hline Soil & $\theta_{\mathrm{s}}(\%)$ & $\theta_{\mathrm{r}}(\%)$ & $n$ & $l$ & $h_{\mathrm{d}}$ \\
\hline Loom & 46.1 & 5.7 & 0.12 & 2 & 33.67 \\
\hline
\end{tabular}

\section{Results and discussion}

\section{Changes in infiltration rates}

Figure 1 shows changes in saturated hydraulic conductivity along the soil profile and linear regressions for saturated hydraulic conductivity from $0 \mathrm{~cm}$ to $15 \mathrm{~cm}$ along soil profiles for treatments 1, 2, and 3. Compared to Fig. 1a-c, the saturated hydraulic conductivity for the three treatments is more variable and covers a wider range (treatment 1 : $0.0241-0.0261 \mathrm{~cm} / \mathrm{min}$; treatment 2: $0.0217-0.0262 \mathrm{~cm} /$ min; treatment 3: $0.0212-0.0280 \mathrm{~cm} / \mathrm{min}$ ). The saturated hydraulic conductivity decreased from 0.024 to $0.021 \mathrm{~cm} /$ min in the presence of a plough plan (Fig. 1a, b), as demonstrated in the previous studies (Wilkinson and Aina 1976; Ankeny et al. 1990, 1995; Freese et al. 1993; Potter et al. 1995; Mohanty et al. 1996; Vervoort et al. 2001; Martínez et al. 2008). The maximum saturated hydraulic conductivity was nearly the same both above the plough pan and without soybean root influence at $0.026 \mathrm{~cm} / \mathrm{min}$. With the addition of soybean roots and stem leaves, the saturated hydraulic conductivity was higher than when measured without soybean coverage $(0.028 \mathrm{~cm} / \mathrm{min})$. These results suggest that saturated hydraulic conductivity is reduced by plough pans and increased by soybean roots. Czarnes et al. (2000) suggested that the stabilization of the soil structure around the root system was due to two interactive effects: an increase in the bond strength between particles and a decrease in the wetting rate. The effect of the root system on soil particles (Czarnes et al. 2000) may increase soil capillary action, ultimately leading to an increase in saturated hydraulic conductivity. Hagedorn and Bundt (2002) reported predominant flow paths in the forest soil of their study. Our results also suggested that our soybean field soil may have had preferential flow paths (Hagedorn and Bundt 2002).

The plough pan located approximately 13-24 cm deep demonstrated the most obvious change in hydraulic conductivity (Fig. 1a-c). The saturated hydraulic conductivity decreases linearly in the soil layer above the plough pan for three treatments, as shown in Fig. 1. Figure 1d-f shows the measured saturated hydraulic conductivity from the surface to a depth of $15 \mathrm{~cm}$ compared with values generated from a linear model. The modelled data for saturated hydraulic conductivity were highly correlated with the measured data (Fig. 1d-f). The RMSEs for simulated and measured data are $0.013 \mathrm{~cm} / \mathrm{h}, 0.035 \mathrm{~cm} / \mathrm{h}$, and $0.021 \mathrm{~cm} / \mathrm{h}$. The coefficients of determination are $0.96,0.91$, and 0.98 . This demonstrates that the linear model accurately captured temporal variations in saturated hydraulic conductivity.

Some researchers have noted that soybean roots are primarily present in the top $15 \mathrm{~cm}$ of soil, particularly when 
Fig. 1 Saturated hydraulic conductivity along the soil profile for no soybean coverage or plough pan (a); no soybean coverage with a plough pan (b); and soybean coverage and a plough pan (c) conditions and linear regressions of saturated hydraulic conductivity along a soil profile from 0 to $18 \mathrm{~cm}$ for three conditions $(\mathbf{d}-\mathbf{f})$
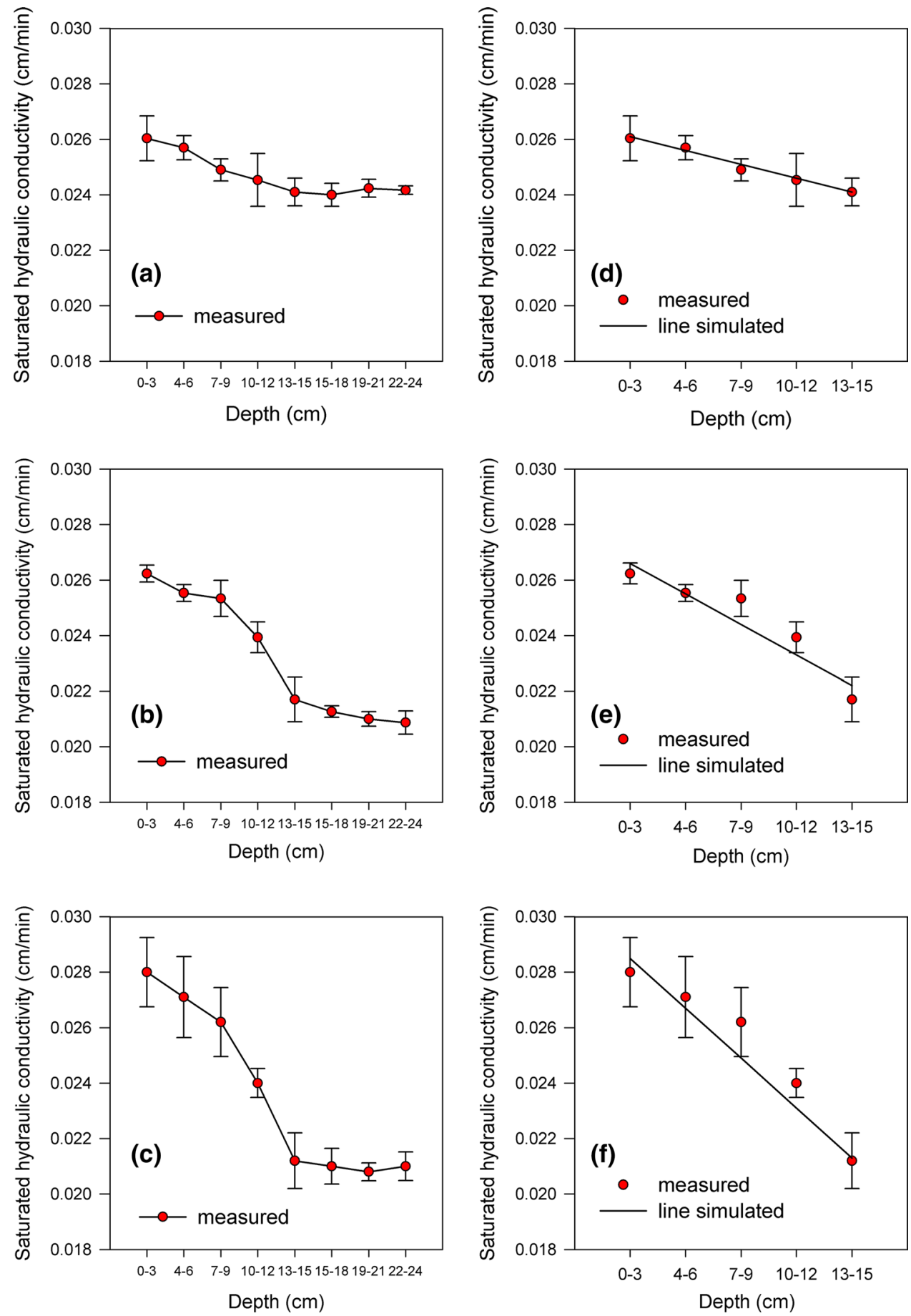

a plough pan is present (Mitchell and Russell 1971; Jin et al. 2007). Due to the alternation of wet and dry conditions and temperature changes when the surface of soil is broken, water conductivity is enhanced. The distribution of large gaps was higher in the $0-15-\mathrm{cm}$ layer than below $15 \mathrm{~cm}$ (Table 4) in 2014 and 2015, especially with a plough pan. The distribution of large gaps in the 15-30$\mathrm{cm}$ layer with a plough pan averaged 0.40 times that of the soil without the plough pan for both years. The plough pan intensified the differences between the $0-15$ and $15-30-\mathrm{cm}$ layers. The increase in soil macropores in the $0-15-\mathrm{cm}$ layer may have been influenced by interspersed plant roots, except for turning the ploughing. The characteristics of the distribution of soil macropores were consistent with previous conclusions (Noguchi et al. 1997; Pierret et al. 2002) on the increase in the number of large gaps caused by plant roots. Under the influences of transmission by a soybean root system and large gaps (Table 4), the saturated 
Table 4 Soil porosity with and without a plough pan (PP)

\begin{tabular}{|c|c|c|c|c|c|c|c|c|}
\hline \multirow[t]{3}{*}{ Depth $(\mathrm{cm})$} & \multicolumn{4}{|l|}{2014} & \multicolumn{4}{|l|}{2015} \\
\hline & \multicolumn{2}{|l|}{ No PP } & \multicolumn{2}{|l|}{ PP } & \multicolumn{2}{|l|}{ No PP } & \multicolumn{2}{|l|}{$\mathrm{PP}$} \\
\hline & Large gap (\%) & $\begin{array}{l}\text { Capillary } \\
\text { porosity }(\%)\end{array}$ & Large gap (\%) & $\begin{array}{l}\text { Capillary } \\
\text { porosity }(\%)\end{array}$ & Large gap (\%) & $\begin{array}{l}\text { Capillary } \\
\text { porosity (\%) }\end{array}$ & Large gap (\%) & $\begin{array}{l}\text { Capillary } \\
\text { porosity } \\
(\%)\end{array}$ \\
\hline $0-15$ & 24.12 & 27.34 & 23.59 & 27.11 & 24.34 & 27.31 & 24.02 & 27.42 \\
\hline $15-30$ & 16.89 & 28.45 & 6.78 & 27.28 & 17.03 & 28.56 & 6.82 & 27.47 \\
\hline $30-45$ & 9.53 & 28.45 & 8.83 & 28.74 & 9.58 & 28.55 & 8.79 & 28.80 \\
\hline $45-60$ & 8.48 & 29.95 & 8.51 & 29.88 & 8.52 & 29.85 & 8.58 & 29.78 \\
\hline $60-75$ & 8.31 & 30.52 & 8.48 & 29.99 & 8.36 & 30.34 & 8.45 & 30.01 \\
\hline
\end{tabular}

hydraulic conductivity of soil near the surface was greater than that at deeper depths; Pierret et al. (2002) reported that the magnetic characteristics of large gaps increased the differences in soil hydraulic conductivity along the soil profile. Our results further indicated that the relationship between saturated hydraulic conductivity and depth was linear (Fig. 1d-f). The linear equation for depth and saturated hydraulic conductivity with soybean coverage and a plough pan for our experiments was:

$K s=-0.0006 x+0.0303$

where $K s$ is the saturated hydraulic conductivity $(\mathrm{cm} / \mathrm{min})$ and $x$ is the depth along the soil profile $(\mathrm{cm})$. The coefficient of determination for the model and experimental data was 0.93 .

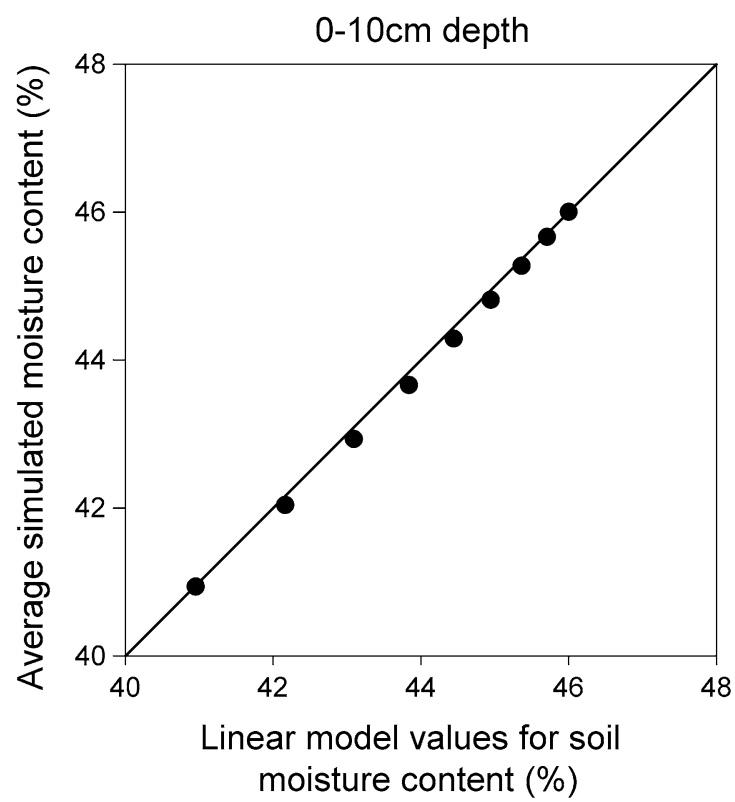

The linear equation could more accurately represent the variation in saturated hydraulic conductivity $(K s)$ in the $0-15-\mathrm{cm}$ layer in the presence of soybean coverage and a plough pan. The constant $K s$ was typically used as a parameter in earlier studies (Gao et al. 2004; Deng et al. 2005; Dong and Wang 2013). Figure 2 shows a comparison of simulated soil moisture using a linear function and the average value of saturated hydraulic conductivity. From depths of $0-10 \mathrm{~cm}$, the soil moisture content modelled with a linear function is higher than the average value, with the reverse being true from depths of $11-25 \mathrm{~cm}$. This is because the average value was less than the modelled value from 0 to $10 \mathrm{~cm}$ and higher than the modelled value from 11 to $25 \mathrm{~cm}$. One particular concern is the discrepancy between simulated and average times from the start of rainfall to the first observation of runoff. The numerical values obtained

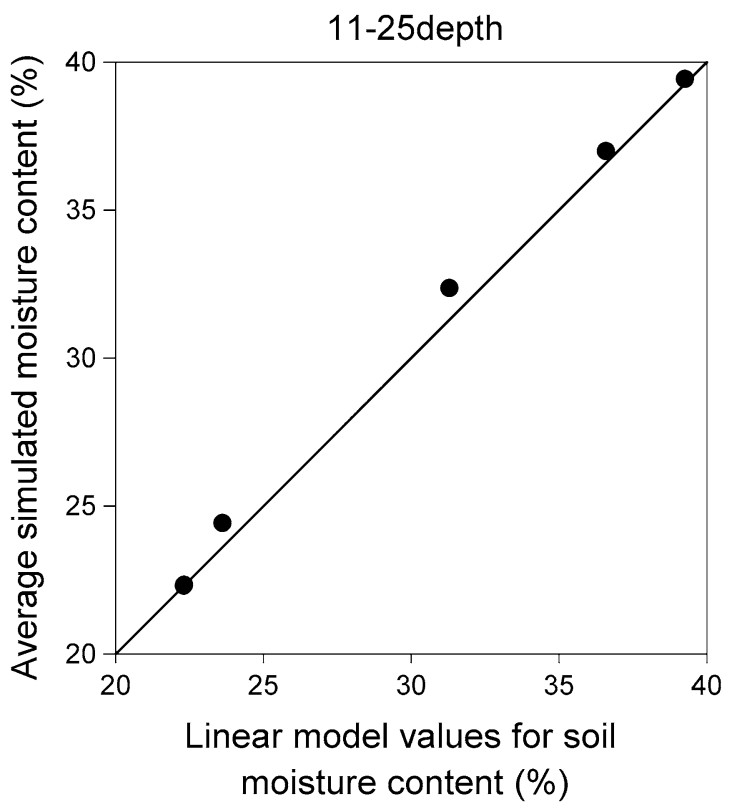

Fig. 2 Model simulation values were compared with either the average saturated water conductivity or the linearly varying saturated water conductivity as a parameter 
by the average saturated hydraulic conductivity are $17 \mathrm{~min}$ and $13 \mathrm{~min}$; thus, a notable discrepancy occurs. To obtain a more accurate measure of $t p$ (the time from the beginning of rainfall to observed runoff), saturated hydraulic conductivity $(K s)$ is a key parameter to use in calculations.

The air entry suction changed with soil bulk density and had a profound impact on infiltration. The bulk density above the plough pan varied little, and the properties of the soil were similar along the profile in our experiments. We thus assumed that air entry suction was constant.

\section{Soil water content in the soil profile}

The saturated water conductivity varied linearly as depth increased when using the numerical method to simulate soil water movement in the profile (Eq. 8). Six experiments (treatment 3 to treatment 8) were used to test the model. The measured and simulated times from the start of rainfall until the start of runoff $(t p)$ and RMSEs are listed in Table 5. The time step in the simulations was $1 \mathrm{~min}$, the spatial step was $1 \mathrm{~cm}$ along the soil profile, and the simulated data agreed very well with the experimental observations, as shown in Table 5. Time to the onset of runoff $(t p)$ is a very important parameter, particularly in the calculation of runoff volume (Gao et al. 2004; Deng et al. 2005; Dong and Wang 2013). If the saturated hydraulic conductivity is larger than the actual saturated hydraulic conductivity, the infiltration of water and the time ( $t p)$ of runoff setup will increase, which will decrease the runoff volume. In contrast, if the saturated hydraulic conductivity is smaller than the actual saturated hydraulic conductivity, the infiltration of water will decrease, the runoff setup time $(t p)$ is shortened, and the runoff volume will be larger. The comparison between simulated and measured values ( $t p)$ and RMSEs (Table 5) shows the superiority of the model parameters which used linear variation in saturated hydraulic conductivity to further illustrate that the linear model of saturated hydraulic conductivity can accurately reflect the water movement process. Soybean branches and leaves protect the soil surface during rain, which minimizes the destruction of soil particles and maintains surface soil porosity. Liu et al. (2015a, b) reported that the maximum interception capacity of soybean was

Table 5 Measured and simulated times $(t p)$ and the RMSEs during two simulated rainfall events

\begin{tabular}{lllll}
\hline Rainfall intensity (cm/min) & $\begin{array}{l}\text { Meas- } \\
\text { ured } t p \\
(\mathrm{~min})\end{array}$ & $\begin{array}{l}\text { Simu- } \\
\text { lated } t p \\
(\mathrm{~min})\end{array}$ & RMSE (\%) \\
\hline With stems and leaves & 0.121 & 11.59 & 13 & 1.11 \\
& 0.148 & 11.62 & 11 & 1.18 \\
Stems and leaves removed & 0.121 & 11.96 & 13 & 0.60 \\
& 0.148 & 12.03 & 11 & 0.93
\end{tabular}

$122.84 \mathrm{~g} / \mathrm{m}^{2}$. The time to the onset of runoff, $t p$, would thus be shorter without than with stems and leaves. Our results, however, suggested the opposite (Table 5), perhaps because the conduction of water by the branches and leaves played a role. Soybean stems and leaves affected the uniformity of the water supply to the surface of the soil and transferred the rainwater that would otherwise have fallen on other locations of our experimental sampling points.

Figure 3 shows a comparison between the model results and the measured experimental soil water content for two different rainfall intensities (artificial rainfall at $0.121 \mathrm{~cm} /$ min and $0.148 \mathrm{~cm} / \mathrm{min}$ ) after $35 \mathrm{~min}$ and $25 \mathrm{~min}$ of rainfall, respectively. Figure 3 demonstrates that the simulated data show a high level of correlation with temporal changes in soil moisture content for the two experiments. The changes in soil moisture content occurred above a depth of $15 \mathrm{~cm}$ in both experiments. In these two experiments, the wetting fronts only slightly contact the plough pan. Rainfall in the study area was heavy and of short duration, so it was difficult for the wetting front to reach the plough pan after a single rain event. In soil $0-8 \mathrm{~cm}$ deep, modelled soil moisture content was lower than measured soil moisture content (Fig. 3). This may be due to the increased water supply to the area around the roots caused by interception and conduction by the stem and leaves. These results agree with those in Table 5. Overall, the effect of the soybean stems and leaves was to transmit the rainwater that should have fallen on other locations by diverting water from the ground sampling area near the plant. The RMSEs values for modelled values and measured values for two simulated rainfalls were $1.11 \%$ and $1.18 \%$.

Figure 4 shows a comparison of model results with the measured experimental soil moisture content for two artificial rainfall experiments in which stems and leaves were removed. By comparing Figs. 3 and 4, we can observe that the model better predicted values for scenarios with stems and leaves removed than with stems and leaves intact; the RMSEs are $0.60 \%$ and $0.93 \%$ (Table 5). The measured times in the runoff setup were $11.96 \mathrm{~min}$ and $12.03 \mathrm{~min}$, closer to modelled values than those with stems and leaves intact (Table 5). These results further illustrate that using a linear model for saturated hydraulic conductivity is the superior approach.

Figure 5 illustrates a comparison of model results with the experimental soil moisture content for two natural rainfall experiments. The measured and simulated $t p$ and RMSEs are shown in Table 6. These results show that the model captured temporal variations in water content in the soil profile under natural rainfall conditions. Because of uneven rainfall intensity, this model is less accurate than the artificial rainfall experiments. However, the results still indicate that by using a linear model of saturated hydraulic conductivity as a parameter, the Richards 

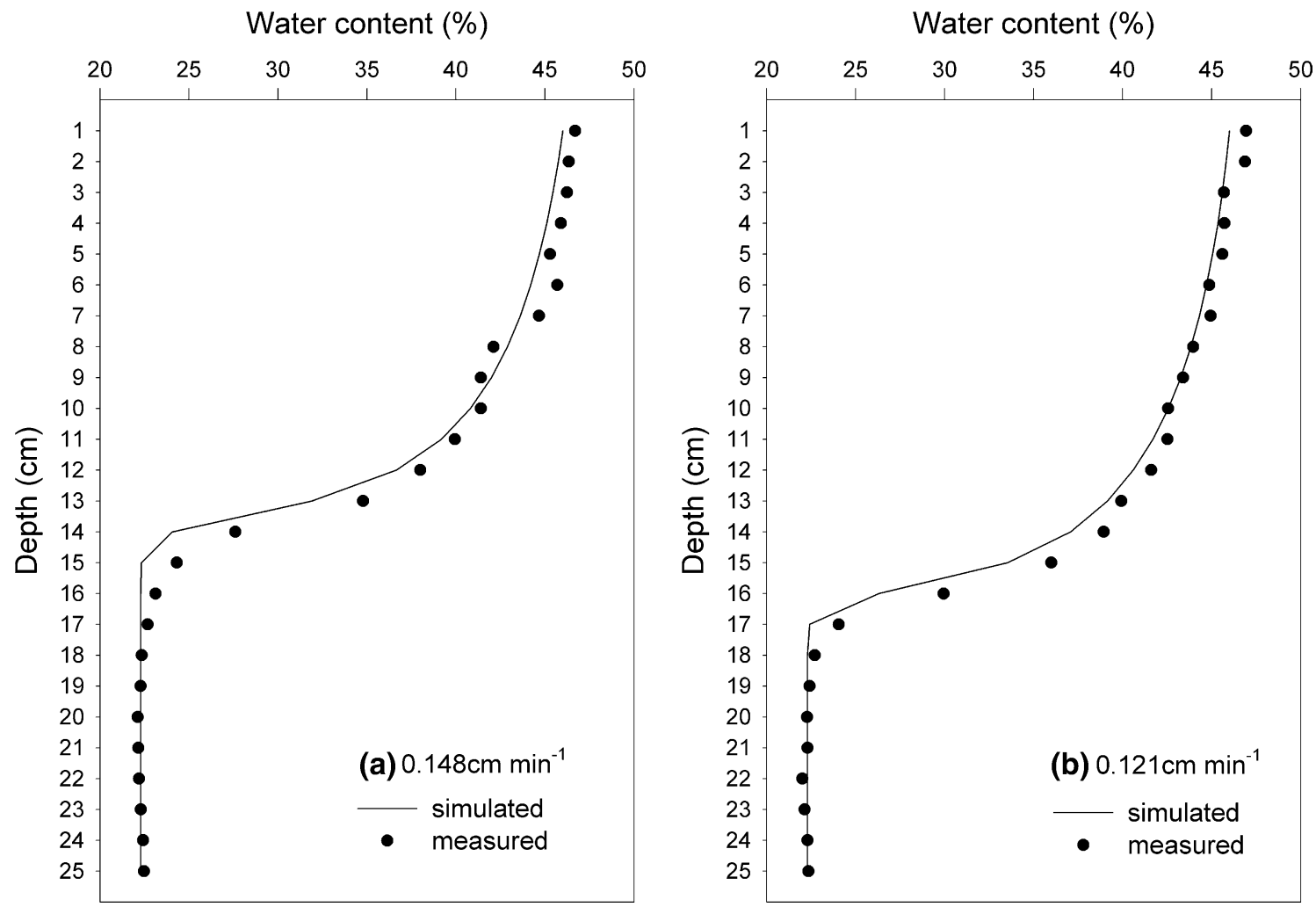

Fig. 3 Comparison of model results with the experimental soil moisture content for two artificial rainfalls with both soybean coverage and existing plough pan conditions

equation can be used to simulate water transport in soil profiles with soybean roots and plough pans.

\section{Sensitivity analysis}

This study primarily focused on changes in saturated hydraulic conductivity in systems affected by the presence of soybean roots and plough pans and how these changes influence the soil water transport model. In the study area, saturated hydraulic conductivity ranged from about 0.021 to $0.028 \mathrm{~cm} / \mathrm{min}$. Thus, we investigated changes in soil water content as saturated hydraulic conductivity changed from 0.021 to $0.028 \mathrm{~cm} / \mathrm{min}$. Figure 6 shows that the simulated data changed with variations in saturated hydraulic conductivity. The $t p$ for three conditions is $8.0,9.0$, and $11.0 \mathrm{~min}(0.021 \mathrm{~cm} / \mathrm{min}, 0.023 \mathrm{~cm} / \mathrm{min}$, and $0.025 \mathrm{~cm} / \mathrm{min}$ ). These results suggest that the wetting front simulated by the Richards equation reaches a greater depth along a soil profile when saturated hydraulic conductivity is increased from 0.021 to $0.025 \mathrm{~cm} / \mathrm{min}$ and that the Richards equation is sensitive to the change of saturated hydraulic conductivity.

\section{Conclusions}

In the study area, the wetting front for a single rainfall is distributed nearly above the plough pan. In the outdoor fields, both bare land and land covered with soybeans had a decrease in infiltration rates from 0 to $15 \mathrm{~cm}$ along the soil profile, particularly when a plough pan was present. Saturated hydraulic conductivity decreased linearly. This is due to the soybean root system transmission and the effect of large gaps on the soil near the surface, which resulted in a greater saturated hydraulic conductivity near the surface than at depth. Soybean stems and leaves affected the uniformity of the water supply to the surface of the soil and transferred the rainwater that would otherwise have fallen on other locations near the bases of the plants. The effect of the transmission of rainwater by the branches and leaves was larger than the interception of rainwater by the branches and leaves. The effect of the root system on the soil particles may increase soil capillary action, further leading to an increase in saturated hydraulic conductivity. The soil of the soybean field may have had preferential flow paths. A linear equation can accurately 
Water content (\%)

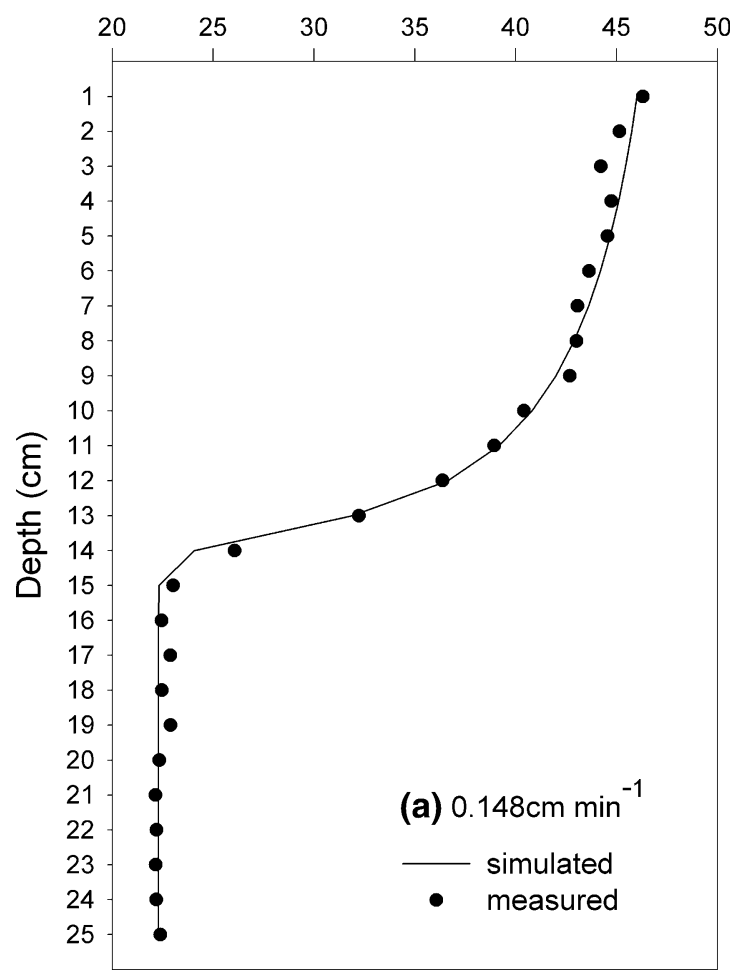

Water content (\%)

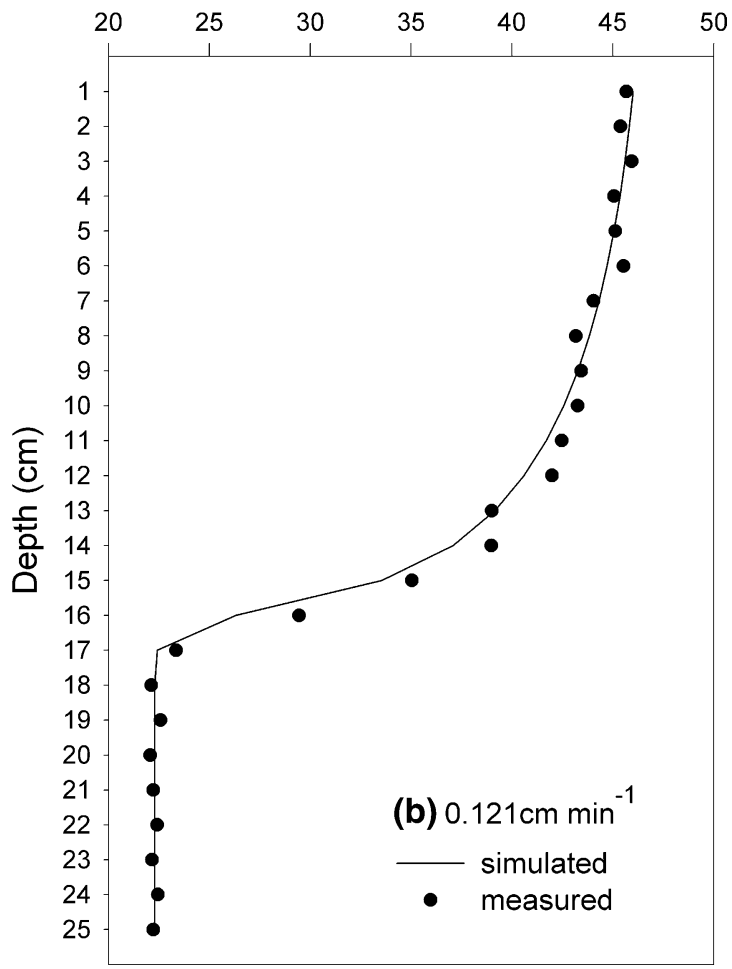

Fig. 4 Comparison of model results with the measured experimental soil moisture content for two artificial rainfall experiments with stems and leaves removed

Water content $(\%)$

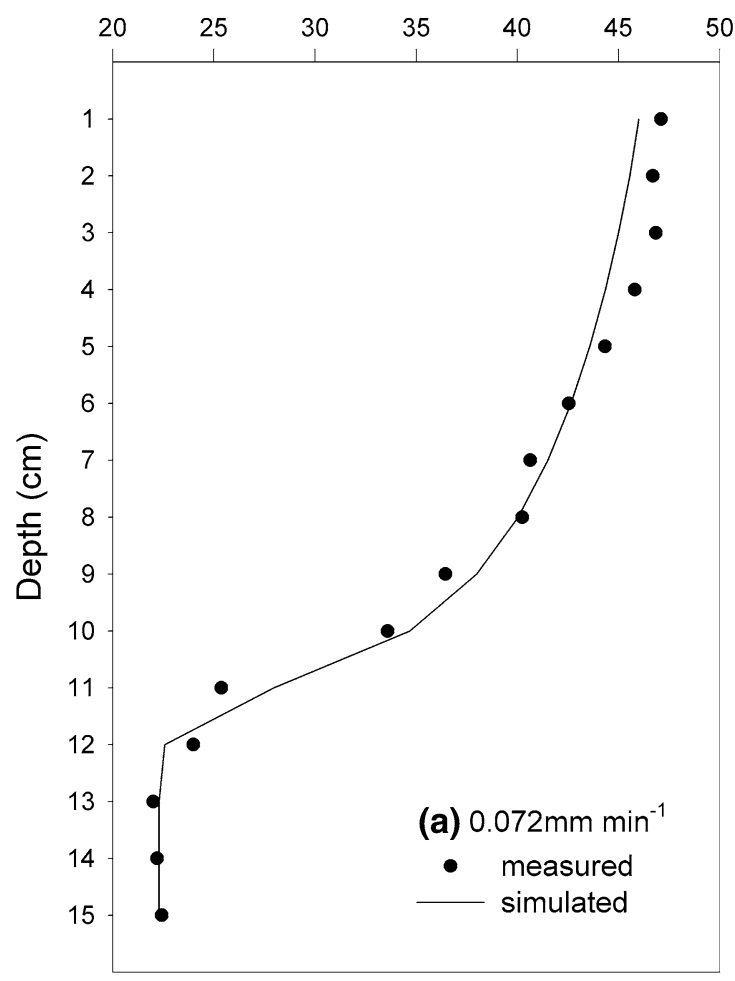

Water content (\%)

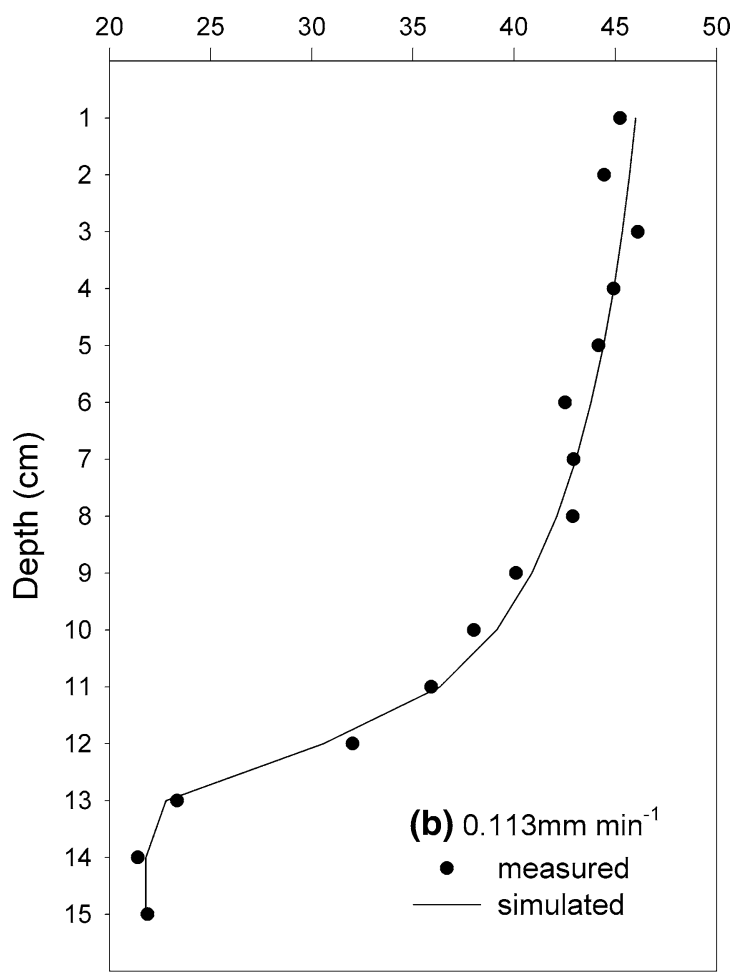

Fig. 5 Comparison of model results with the experimental soil moisture content for two natural rainfall experiments 
Table 6 Measured and simulated times ( $t p)$ and RMSEs for simulated values and measured values of for natural rainfall events

\begin{tabular}{llll}
\hline $\begin{array}{l}\text { Rainfall intensity } \\
(\mathrm{mm} / \mathrm{min})\end{array}$ & $\begin{array}{l}\text { Measured } t p \\
(\mathrm{~min})\end{array}$ & $\begin{array}{l}\text { Simulated } t p \\
(\mathrm{~min})\end{array}$ & RMSE (\%) \\
\hline 0.072 & 43.21 & 39 & 1.20 \\
0.113 & 18.45 & 17 & 0.81 \\
\hline
\end{tabular}

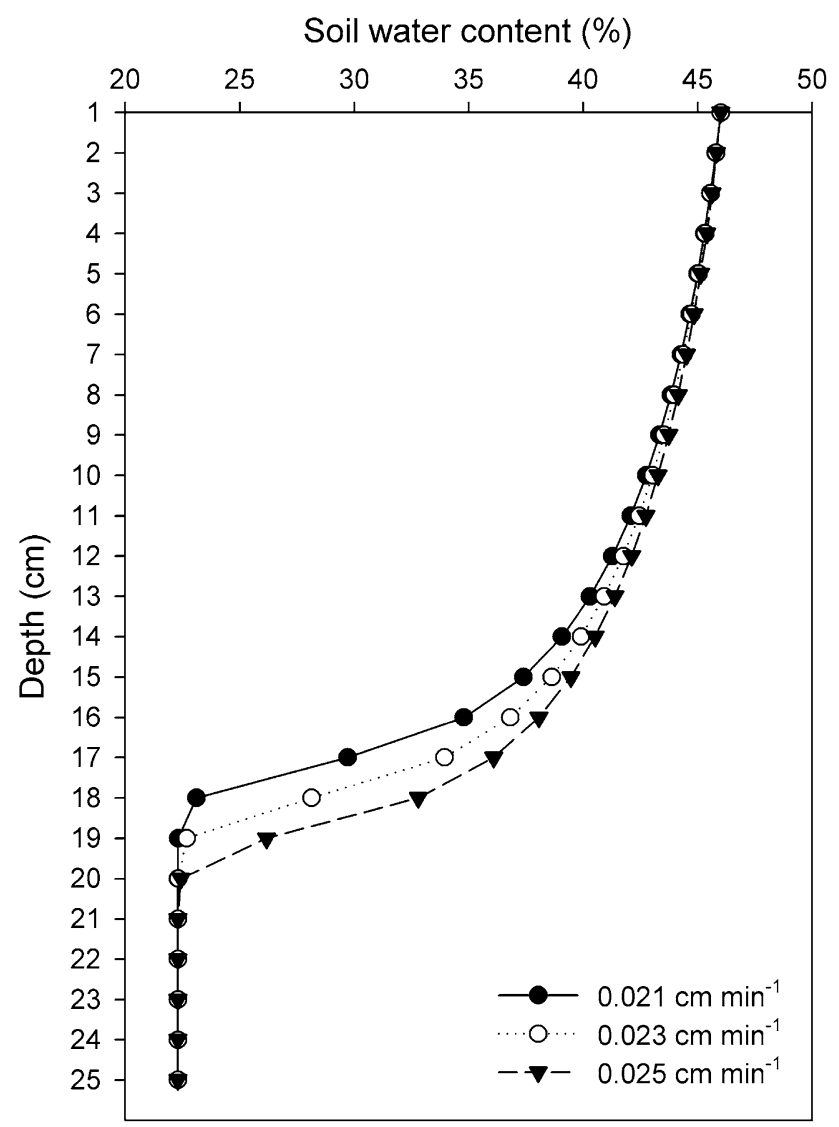

Fig. 6 Changes in simulated soil water content with variations in saturated hydraulic conductivity

reflect variation in saturated hydraulic conductivity above plough pan. Using a linear model for saturated hydraulic conductivity as parameter, the Richards equation can accurately simulate soil water transport a long a soil profile under rainfall conditions.

Acknowledgements We thank the reviewers and editors for their suggestions and helpful comments.

Funding This research was supported by the National Natural Science Foundation of China (41301288), the Natural Science Foundation of Heilongjiang Province (E2018010), the postdoctoral scientific research developmental fund of the Heilongjiang Province (No. LBH-Q17020), and the Young Talents Project of Northeast Agricultural University, China (14QC48).

\section{Compliance with ethical standards}

Conflict of interest The authors declare that they have no conflict of interest.

Open Access This article is distributed under the terms of the Creative Commons Attribution 4.0 International License (http://creativecommons.org/licenses/by/4.0/), which permits unrestricted use, distribution, and reproduction in any medium, provided you give appropriate credit to the original author(s) and the source, provide a link to the Creative Commons license, and indicate if changes were made.

\section{References}

Alakukku L (1996a) Persistence of soil compaction due to high axle load traffic. I. Short-term effects on the properties of clay and organic soils. Soil Tillage Res 37(4):211-222

Alakukku L (1996b) Persistence of soil compaction due to high axle load traffic. II. Long-term effects on the properties of fine-textured and organic soils. Soil Tillage Res 37(4):223-238

Ankeny MD, Kaspar TC, Horton R (1990) Characterization of tillage and traffic effects on unconfined infiltration measurements. Soil Sci Soc Am J 54(3):837-840

Ankeny MD, Kaspar TC, Prieksat MA (1995) Traffic effects on water infiltration in chisel-plow and no-till systems. Soil Sci Soc Am J 59(1):200-204

Arvidsson J (2001) Subsoil compaction caused by heavy sugarbeet harvesters in southern Sweden: I. Soil physical properties and crop yield in six field experiments. Soil Tillage Res 60(1-2):67-78

Bertolino AVF, Nelson Fernandes NF, Miranda JPL et al (2010) Effects of plough pan development on surface hydrology and on soil physical properties in Southeastern Brazilian plateau. J Hydrol 393:94-104

Beven K, Germann PF (1982) Macropores and water flow in soils. Water Resour Res 18(5):1311-1325

Boizard H, Richard G, Roger-Estrade J et al (2002) Cumulative effects of cropping systems on the structure of the tilled layer in northern France. Soil Tillage Res 64(1-2):149-164

Brooks RH, Corey AJ (1964) Hydraulic properties of porous media. Colorado State University, Fort Collins

Cullum RF (2009) Macropore flow estimations under no-till and till systems. CATENA 78:87-91

Czarnes S, Hallett PD, Bengough AG et al (2000) Root and microbialderived mucilage's affect soil structure and water transport. Eur J Soil Sci 51:435-443

Deng ZQ, de Lima JLMP, Singh VP (2005) Transport rate-based model for overland flow and solution transport: Parameter estimation and process simulation. J Hydrol 315(1-4):220-235

Dong WC, Wang QJ (2013) Modelling Soil solute release into runoff and transport with runoff on a loess slope. J Hydrol Eng 18:527-535

Dong WC, Fu Q, Wang QJ et al (2017) Effect of plough pans on the growth of soybean roots in the black soil region of north-eastern China. J Integr Agric 16(10):2191-2196

Freese RC, Cassel DK, Denton HP (1993) Infiltration in a Piedmont soil under three tillage systems. J Soil Water Conserv 48(3):214-218

Fu XL, Shao MA, Lu DQ (2008) Quantitative relationship between mass water content pressure head and bulk density in determination of soil water retention characteristics. Undisturb Soils Acta Pedol Sin 45(1):50-55 (in Chinese) 
Gantzer CJ, Anderson SH (2002) Computed tomographic measurement of macroporosity in chisel-disk and no-tillage seedbeds. Soil Tillage Res 64(1-2):101-111

Gao B, Walter MT, Steenhuis TS et al (2004) Rain induced chemical transport from soil to runoff: theory and experiments. J Hydrol 295(1-4):291-304

Gao B, Walter MT, Steenhuis TS et al (2005) Investigating raindrop effects on transport of sediment and non-sorbed chemicals from soil to surface runoff. J Hydrol 308:313-320

Greco R (2002) Preferential flow in macroporous swelling soil with internal catchment: model development and applications. J Hydrol 269:150-168

Hagedorn F, Bundt M (2002) The age of preferential flow paths. Geoderma 108:119-132

Horn R, Domzzal H, Slowinska-Jurkiewicz A et al (1995) Soil compaction processes and their effects on the structure of arable soils and the environment. Soil Tillage Res 35(1-2):23-36

Huang J, Wu PT, Zhao XN (2010) Impact of slope biological regulated measures on soil water infiltration. Trans CSAE 26(10):29-37 (in Chinese)

Jin J, Wang GH, Liu XB et al (2007) Characteristics of root distribution at R5 stage in high yielding soybean in black soil. Chin J Oil Crop Sci 29(3):266-271 (in Chinese)

Lamandé M, Labouriau R, Greve HM et al (2011) Density of macropores as related to soil and earthworm community parameters in cultivated grasslands. Geoderma 162:319-326

Liebig MA, Jones AJ, Mielke LN et al (1993) Controlled wheel traffic effects on soil properties in ridge tillage. Soil Sci Soc Am J 57(4):1061-1066

Liu DS, Li WB (1983) Simple method for determining soil bulk density and porosity. Chin J Soil Sci 4:44-47 (in Chinese)

Liu YL, Qj W, Yang T et al (2015a) Study on interception characteristics of different plants. J Soil Water Conserv 29(3):172-177 (in Chinese)

Liu MF, Hu XP, Liao YT et al (2015b) Morphological parameters characteristics of mechanically transplanted plant in suitable transplanting period for different rape varieties. Trans Chin Soc Agric Eng 31(1):79-88 (in Chinese)

Logsdon SD, Allmaras RR, Nelson WW et al (1992) Persistence of subsoil compaction from heavy axle loads. Soil Tillage Res 23(1-2):95-110

Martínez E, Fuentes J-P, Silva P et al (2008) Soil physical properties and wheat root growth as affected by no-tillage and conventional tillage systems in a Mediterranean environment of Chile. Soil Tillage Res 99(2):232-244

Mitchell RL, Russell WJ (1971) Root development and rooting patterns of soybeans Glycine max (L.) Merrill evaluated under field conditions. Agron J 63:313-316

Mohanty BP, Horton R, Ankeny MD et al (1996) Infiltration and macroporosity under a row crop agricultural field in a glacial till soil. Soil Sci 161(4):205-213

Mooney SJ (2002) Three-dimensional visualization and quantification of soil macroporosity and water flow patterns using computed tomography. Soil Use Manag 18:142-251
Noguchi S, Nik AR, Kasran B et al (1997) Soil physical properties and preferential flow pathways in tropical rain forest, Bukit Tarek, Peninsular Malaysia. J For Res 2(2):115-120

Parlange JY (1971) Theory of water-movement in soils: I. One-dimensional absorption. Soil Sci 111(2):134-137

Parlange JY (1972) Theory of water movement in soils: I. Onedimensional infiltration with constant flux at the surface. Soil Sci 114:1-4

Pierret A, Capowiez Y, Belzunces L et al (2002) 3D reconstruction and quantification of macropores using $\mathrm{X}$-ray computed tomography and image analysis. Geoderma 106:247-271

Potter KN, Torbert HA, Jr M et al (1995) Tillage and residue effects on infiltration and sediment losses on vertisols. Trans ASAE 38(5):1413-1419

Qu ZQ, Jia LQ, Jin HY et al (1999) Formation of soil macropores and preferential migration of linear alkylbenzene sulfonate (LAS) in soils. Chemosphere 38(9):1985-1996

Radford BJ, Bridge BJ, Davis RJ et al (2000) Changes in the properties of a Vertisol and responses of wheat after compaction with harvester traffic. Soil Tillage Res 54(3-4):155-170

Richard G, Boizard H, Roger-Estrade J et al (1999) Field study of soil compaction due to traffic in northern France: pore space and morphological analysis of the compacted zones. Soil Tillage Res 51(1-2):151-160

Vervoort RW, Dabney SM, Romkens MJM (2001) Tillage and row position effects on water and solute infiltration characteristics. Soil Sci Soc Am J 65(4):1227-1234

Wallach R, William AJ, William FS (1988) Transfer of chemical from soil solution to surface runoff: a diffusion-based soil model. Soil Sci Soc Am J 52:612-617

Wang ZF, Yang YH, Zhao ZH et al (1996) Study on soil mechanical in anti-water erosion ability of soil-root composite. J China Agric Univ 1(2):39-45

Wang QJ, Horton R, Shao MA (2002) Horizontal infiltration method for determining Brooks-Corey model parameters. Soil Sci Soc Am J 66(6): 1733-1739

Wilkinson GE, Aina PO (1976) Infiltration of water into two Nigerian soils under secondary forest and subsequent arable cropping. Geoderma 15(1):51-59

Willmott CJ (1982) Some comments on the evaluation of model performance. Bull Am Meteorol Soc 63(11):1309-1317

Xu D, Mermoud A (2001) Topsoil properties as affected by tillage practices in North China. Soil Tillage Res 60:11-19

Yuan JP, Jiang DS, Wen MX (1999) A device for measuring soil infiltration rate on hill slope. Soil Water Conserv Bull 19(1):24-27 (in Chinese)

Publisher's Note Springer Nature remains neutral with regard to jurisdictional claims in published maps and institutional affiliations. 